\title{
PEMANFAATAN TUMBUHAN SUMBER PANGAN DI DESA SETIA JAYA KECAMATAN TERIAK KABUPATEN BENGKAYANG
}

(Utilization of source food plants in forest Tembawang Village Setia Jaya Bengkayang District)

\author{
Mega Kristina, Togar F. Manurung, Lolyta Sisillia \\ Fakultas Kehutanan Universitas Tanjungpura Jalan Imam Bonjol, Pontianak 78124 \\ Email: megakristina17@gmail.com
}

\begin{abstract}
The research objective was to determine the plant food sources used by the people of Setia Jaya Village, Teriak District, Bengkayang Regency. The research was conducted on 11 April 2019 9 May 2019. The research method used a survey method, while the interviews were conducted using a snowball sampling technique. Based on the research conducted, 50 plant species were found with 28 types of families, namely Anarcaceae, Verberanaceae, Oxalidaceae, Moraceae, Malvaceae, Euphorbiaceae, Myrtaceae, Fabaceae, Auriculariaceae, Sapindaceae, Melastomataceae, Bromeliaceae, Annonaceae, Poaceae, Arecaceae, Piperceae, Meliaceae, Passifloraceae, Zigiberaceae, Solanaceae, Robiaceae, Dryopteriaceae, Gnetaceae, Blechnaceae, Schizophyllaceae, Caricaceae, Tricholomataceae and Bombaceae. Food source plants have use values as follows: mango, star fruit, durian, rubber, papaya, koko, red fern, green fern, jackfruit, soursop, petai, bamboo shoots and cassava as much as 1, starfruit, bebuas, cempedak, as much as durian kawai. 0.966667, Lingkodok as much as 0.766667, durian kawai as much as 0.966667, water guava, taro, melinjo, and mentawa as much as 0.6, guava as much as 0.7, kedondong and langsat as much as 0.666667, longan and purple eggplant 0.63333, candlenut as much as 0.233333, white mushrooms as much as 0.266667, fungus and ear mushrooms as much as 0.2, kelampai and pineapple as much as 0.3, areca as much as 0.933333, sago as much as 0.366667, pepper, salak and bay leaves as much as 0.5, lelatup as much as 0.166667 , betel and breadfruit as much as 0.466667 , tamarind eggplant as much as 0.566667 and ciplukan as much as 0.4.
\end{abstract}

Keywords: Food Plants, Tembawang Forest, Utilization

\section{PENDAHULUAN}

Indonesia dikenal sebagai Negara agraris yang berarti Negara yang mengandalkan sektor pertanian baik sebagai sumber mata pencarian masyarakat maupun sebagai sektor penopang pembangunan (Saragih, 2001). Kalimantan Barat dengan luas daerah $146.807 \mathrm{~km}^{2}$ menyimpan banyak keanekaragaman hayati, salah satunya tumbuhan berpotensi bahan pangan (Badan Pusat Statistik, 2012) Wujud kontribusi hutan terhadap ketersediaan pangan secara langsung adalah optimalisasi pemanfaatan sumberdaya hutan sebagai penyedia pangan (Forest for Food Production). Ketersediaan pangan yang bersumber dari hutan dan diperoleh melalui manfaat langsung plasma nuflah flora dan fauna untuk pemenuhan kebutuhan pangan hingga papan (Kemenhut, 2010).

Kontribusi hutan ini seiring dengan peraturan presiden N0. 83 tahun 2006 tentang dewan kehutanan pangan, dimana kementrian kehutanan adalah salah satu sektor yang turut bertanggung jawab terhadap ketahanan pangan. Kuswijayati et al dalam Suhardi et al (2002) menyakan bahwa sedikitnya dari hutan terdapat 77 
jenis bahan pangan dari karbohidrat, 26 jenis kacang-kacangan, 389 jenis biji-bjian dan buah-buahan, 288 jenis sayur-sayuran, 110 jenis rempah-rempah dan bumbubumbuan, 75 jenis minyak dan lemak, 40 jenis bahan minuman serta 1.260 jenis tanaman obat. Hal ini menunjukkan bahwa hutan memiliki potensi yang besar dalam memberikan kontribusi penyediaan pangan bagi masyarakat.

Berdasarkan hasil penelitian Sumarlin et al (2015), penelitian selama 4 minggu pada kawasan Hutan Tembawang Aur Sampuk Kecamatan Sengah Temila Kabupaten Landak ditemukan sebanyak 36 jenis tanaman pangan yang dapat dikonsumsi oleh masyarakat, yang terdiri dari 13 jenis kelompok sayur-sayuran, 2 jenis kelompok umbi-umbian, 2 jenis kelompok jamur-jamuran dan 1 jenis kelompok tebu-tebuan. Hal ini disebabkan oleh beberapa faktor seperti Desa tersebut merupakan daerah daratan rendah dan sebagian adalah paya (tanah berlumpur), dataran yang demikian memiliki nilai sangan penting untuk tumbuhnya berbagai jenis tanaman, sehingga jenis tanaman lebih banyak. keanekaragamannya. Menurut Gamaruddin et al (2004), bahwa penelitian tentang pemanfaatan tumbuhan secara tradisional dan pengolaanya tidak hanya aspek fisik dan kandungan kimianya, tetapi juga aspek ekologi, proses domestika, sistem pertanian tradisional, penanaman jenis lokal dan pengolahannya menurut masyarakat setempat.

Masyarakat Desa Setia Jaya juga memanfaatkan hasil tanaman dari hutan tembawang sebagai sumber pangan bagi mereka, seperti memanfaatkan hasil buah yang dapat mereka makan secara langsung, maupun buah-buahan yang mereka olah menjadi lauk ataupun yang mereka olah menjadi makanan ringan. Hutan tembawang di Desa setia Jaya Kecamatan Teriak Kabupaten Bengkayang terletak di dekat pemukiman penduduk dan mempunyai kawasan yang memiliki flora dan fauna cukup banyak salah satunya adalah tanaman yang berpotensi sebagai tumbuhan pangan lokal. Sampai saat ini data dan informasi tumbuhan sumber pangan yang dimanfaatkan masyarakat pada hutan tembawang Desa Setia Jaya Kecamatan Teriak Kabupaten Bengkayang masih sangat terbatas. Untuk itu, perlu dilakukan penelitian tentang tumbuhan sumber pangan yang dimanfaatkan oleh masyarakat sekitar hutan tembawang Desa Setia Jaya Kecamatan Teriak Kabupaten Bengkayang dalam upaya pengembangan dan pembudidayaan tumbuhan sumber pangan yang mempunyai potensi sebagai sumber pangan yang berkelanjutan.

\section{METODOLOGI PENELITIAN}

Penelitian dilaksanakan di Desa Setia Jaya Kecamatan Teriak Kabupaten Bengkayang pada tanggal 11 April 2019 sampai dengan 9 Mei 2019 efektif lapangan. Alat dan bahan yang digunakan dalam penelitian ini adalah peta lokasi, GPS, parang, kamera, tally sheet, tali rapiah, peralatan pengumpulan specimen (penggaris, kain hitam dan galah), buku atau referensi untuk mengidentifikasi tumbuhan, alat pembuatan herbarium (Koran, alkohol, plastik, isolasi, label gantung).

\section{Metode Penelitian}


Penelitian ini dilakukan dengan menggunakan metode Survey, dengan teknik eksplorasi yaitu menjelajahi setiap sudut lokasi yang dapat mewakili tipe-tipe ekosistem atau tipe-tipe vegetasi dikawasan yang diteliti Rugayah et al, (2004). Teknik ini dilakukan dengan tujuan untuk mengetahui secara pasti keadaan lokasi penelitian, sehingga dapat diketahui dengan pasti lokasi-lokasi dimana jalur-jalur penelitian akan diletakkan secara tegak lurus di seluruh kawasan sebanyak 5 jalur dengan panjang 100 meter dan lebar 20 meter $(10$ meter ke kanan dan 10 meter ke kiri).Selanjutnya untuk mengetahui jenis tanaman pangan yang digunakan oleh masyarakat menggunakan kuisioner wawancara sebagai pedoman. Pembuatan herbarium akan dilakukan untuk tumbuhan yang belum diketahui nama ilmiahnya. Proses pembuatan herbarium dapat di lakukan dengan dua cara yaitu dengan cara kering dan cara basah. - Cara Kering Herbarium kering biasanya daun, batang dan akar. Pembuatan herbarium kering ketika pengambilan spesimen di lapangan, langsung di pres dan di keringkan tidak di siram atau di rendam dengan alkohol atau bahan sejenisnya terlebih dahulu. Biasanya hal ini dilakukan karna karena jarak antara pengambilan spesimen dilapangan dan tempat pengeringan dekat, tidakmenempuh waktu berhari-hari $(<$ dari 6 jam). Bila lebih dari itu dikhawatirkan spesimen akan rusak. - Cara Basah Herbarium basah digunakan untuk spesimen yang berbanir dan biasanya organ tumbuhan yang berdaging seperti buah Setyawan et al (2005). Pembuatan herbarium basah ketika pengambilan spesimen dilapangan tidak langsung dikeringkan, namun dibungkus terlebih dahulu dalam lipatan koran, dimasukkan ke dalam wadah plastik atau wadah yang tidak bocor. Kemudian siram dengan alkohol atau jenis bahan pengawet lainnya sehingga membasahi kertas Koran tersebut lalu ditutup dengan rapat. Cara ini dilakukan apabila spesimen diambil jauh dari tempat proses pengeringan, atau menempuh waktu berhari-hari lebih dari 6 jam Ambriansyah (2010).

\section{Teknik Pengumpulan Data}

Data yang diambil dalam penelitian ini adalah data primer dan data sekunder. Data primer merupakan data yang diperoleh secara langsung melalui wawancara responden terepilih dan pengamatan dilapangan secara langsung sesuai dengan ciri lahan tumbuhan sumber pangan yang meliputi :

1. Nama jenis

2. Ciri-ciri Spesifik dari jenis tumbuhan sumber pangan

3. Habitat

4. Habitus

5. Famili

6. Satus di alam

Data sekunder merupakan data yang diperoleh secara tidak langsung, data dapat diperoleh dari keadaan umum lokasi penelitian, studi literature, laporan hasil penelitian, internet, jurnal dan lainlain.

\section{Analisis Data}

Data yang diperoleh dari hasil pengamatan di lapangan akan dicatat langsung ke dalam tally sheet, kemudian deskripsikan sesuai dengan ciri-ciri fisik tanaman pangan data yang diambil 
dimasukkan kedalam tabel daftar jenis tumbuhan yang ditulis menggunakan nama latin sesuai Binomial Nomenclature beserta nama lokalnya dan penulisan dikelompokkan bersama familinya masing-masing.

\section{Analisis Use Value (UV)}

Jenis dan pemanfaatan tumbuhan suber pangan yang diperoleh dapat dianalisis dengan menggunakan nilai $U s e$ Value (UV). Untuk mengetahui spesies tumbuhan yang dianggap penting dianalisis dengan menggunakan nilai Use Value dengan rumus:

$$
\mathrm{UVis}=\frac{\sum \mathrm{Uis}}{\text { nis }}
$$

Keterangan:

UVis : Nilai (Use Value)

$\Sigma$ Uis : Jumlah seluruh pengguna spesies tumbuhan tertentu yang dijelaskan setiap kali bertanya

nis : Jumlah total informan yang diwawancarai

\section{Analisis Family Importance Value (FIV)}

Mengetahui famili pada spesies tumbuhan yang paling banyak digunakan (Napagoda, 2015). dihitung dengan menggunakan rumus berikut:

$$
\mathrm{FIV}=\frac{\mathrm{FC}(\text { family })}{\mathrm{N}} \times 100
$$

Keterangan:

FIV : Nilai (Family Importance Value)

FC : Jumlah responden yang

menyebutkan famili tiap spesies tumbuhan

$\mathrm{N}$ : Jumlah total responden

\section{Persentasi Famili}

Kemudian untuk mengetahui persentase family, persentase bagian tumbuhan yang digunakan, persentase cara pengolahannya, dan persentase kelompok pangan dengan menggunakan rumus sebagai berikut :

a) Persentase family

$$
\frac{(\text { Family tertentu })}{(\text { Seluruh tanaman })} \times 100 \%
$$

b) Persentase bagian yang digunakan $\frac{\text { (Bagian tanaman yang digunakan) }}{\text { (Seluruh tanaman) }} \times 100 \%$

c) Persentase cara pengolahannya

$$
\frac{\text { (Cara pengolahan })}{(\text { Seluruh tanaman })} \times 100 \%
$$

d) Persentase kelompok pangan

$$
\frac{(\text { Kelompok pangan })}{(\text { Seluruh tanaman })} \times 100 \%
$$

\section{HASIL DAN PEMBAHASAN}

Berdasarkan hasil pengamatan dikawasan Hutan Tembawang Desa Setia Jaya Kecamatan Teriak Kabupaten Bengkayang, ditemukan sebanyak 50 jenis tanaman yang tergolong dalam 28 famili, pada kawasan Hutan Tembawang Desa Setia Jaya Kecamatan Teriak Kabupaten Bengkayang. Adapun nama-nama tumbuhan sumber pangan yang ditemukan pada keseluruhan jalur pengamatan tertera pada Lampiran 1.

Dari hasil wawancara dengan masyarakat disekitar hutan tembawang Desa Setia jaya serta hasil survey lapangan terdapat 50 jenis tumbuhan sumber pangan seperti yang tertera pada Lampiran 1. Umumnya dari jenis-jenis tumbuhan sumber pangan tersebut bagian yang digunakan untuk dikonsumsi adalah buah, daun, umbi, tunas muda, biji serta umbut, sedangkan pengelolahan untuk dijadikan makanan biasanya dikonsumsi langsung atau diolah.

Masyarakat disekitar hutan tembawang Desa Setia Jaya Kecamatan Teriak Kabupaten Bengkayang mengolah 
sumber pangan tidak hanya menggunakan satu jenis tumbuhan sumber pangan saja, tetapi dicampur dengan bahan lainnya. Pengolahan dan penggunaan tumbuhan sumber pangan sangat sederhana ini sangat berkaitan dengan pengetahuan masyarakat tentang tumbuhan pangan yang umumnya diperoleh secara turuntemurun dan berdasarkan pada kebiasaan dan pengalaman mereka sehari-hari. Pemanfaatan tumbuhan sumber pangan dirasakan masyarakat merupakan cara paling efektif untuk memenuhi kebutuhan pangan karena dari segi biayanya yang murah dan tumbuhannya dapat diperoleh pada daerah sekitar kawasan hutan.

\section{Analisis Use Value (UV)}

Berdasarkan hasil penelitian yang dilakukan di Desa Setia Jaya Kecamatan Teriak Kabupaten Bengkayang, ditemukan 50 jenis tumbuhan dari 28 famili yang dimanfaatkan oleh masyarakat sekitar hutan tembawang. Rekapitulasi jenis tumbuhan berdasarkan family yang digunakan sebagai tumbuhan sumber pangan oleh masyarakat Desa Setia Jaya
Kecamatan Setia Jaya Kabupaten Bengkayang dapat dilihat pada Lampiran 2.

Dari hasil analisis Use Value (UV) tumbuhan sumber pangan memiliki nilai guna sebagai berikut tanaman Mangga, belimbing, durian, karet, papaya, koko, pakis merah, pakis hijau, nangka, sirsak, petai, rebung dan ubi kayu sebanyak 1, belimbing wuluh, bebuas, cempedak, durian kawai sebanyak 0,966667, lingkodok sebanyak 0,766667, durian kawai sebanyak 0,966667, jambu air, keladi, melinjo, dan mentawa sebanyak 0,6, jambu batu sebanyak 0,7, kedondong dan langsat sebanyak 0,666667 , lengkeng dan terung ungu sebanyak 0,63333, kemiri sebanyak 0,233333, jamur putih sebanyak 0,266667, cendawan dan jamur kuping sebanyak 0,2, kelampai dan nanas sebanyak 0,3, pinang sebanyak 0,933333, sagu sebanyak 0,366667, lada, salak dan daun salam sebanyak 0,5 , lelatup sebanyak 0,166667, sirih dan sukun sebanyak 0,466667 , terung asam sebanyak 0,566667 dan ciplukan sebanyak 0,4 .

\section{Analisis Family Importance Value (FIV)}

Tabel 1. Analisis Family Importance (FIV)

\begin{tabular}{clrrlr}
\hline No & \multicolumn{1}{c}{ Family } & FIV & No & Family & FIV \\
\hline 1 & Anarcadiaceae & 83.3333 & 15 & Meliaceae & 58.3333 \\
2 & Annonaceae & 100 & 16 & Moraceae & 72.6666 \\
3 & Arecaceae & 60 & 17 & Myrtaceae & 58.3333 \\
4 & Auriculariaceae & 20 & 18 & Oxalidaceae & 98.3333 \\
5 & Blechnaceae & 100 & 19 & Passifloraceae & 16.6666 \\
6 & Bombaceae & 100 & 20 & Piperaceae & 48.3333 \\
7 & Bromeliaceae & 30 & 21 & Poaceae & 100 \\
8 & Caricaceae & 100 & 22 & Rubiaceae & 53.3333 \\
9 & Dryoteridaceae & 100 & 23 & Sapindaceae & 61.6666 \\
10 & Euphorbiaceae & 63.3333 & 24 & Schizophyllaceae & 20 \\
11 & Fabaceae & 85 & 25 & Solanaceae & 53.3333 \\
12 & Gnetaceae & 53.3333 & 26 & Tricholomataceae & 26.6666 \\
13 & Malvaceae & 98.3333 & 27 & Verbenaceae & 96.6666 \\
14 & Melastomataceae & 76.6666 & 28 & Zingiberaceae & 56.6666 \\
\hline
\end{tabular}

Sumber Data : Analisis Data 2019 


\section{Jenis Tumbuhan Berdasarkan Famili}

Berdasarkan hasil penelitian yang dilakukan di Desa Setia Jaya Kecamatan Teriak Kabupaten Bengkayang, ditemukan 50 jenis tumbuhan dari 28 famili yang dimanfaatkan oleh masyarakat sekitar hutan tembawang. Rekapitulasi jenis tumbuhan berdasarkan family yang digunakan sebagai tumbuhan sumber pangan oleh masyarakat Desa Setia Jaya Kecamatan Setia Jaya Kabupaten Bengkayang dapat dilihat pada Gambar 1 .

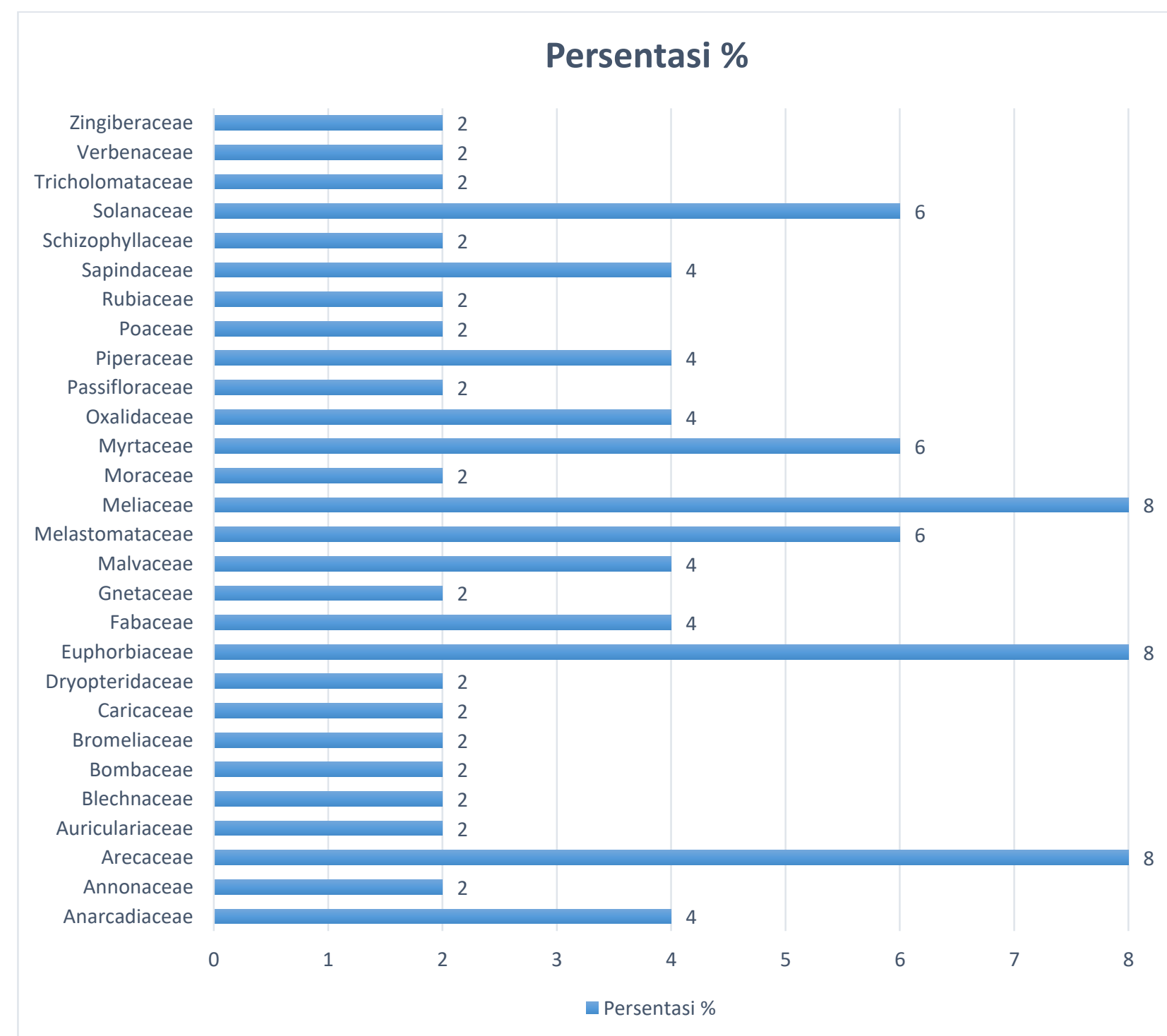

Gambar 1. Dominasi Famili Tumbuhan Sumber pangan

Gambar 1. menunjukan tumbuhan di jumpai adalah Meliaceae, pangan berdasarkan family yang di Euphorbiaceae, dan Arecaceae dengan temukan di hutan tembawang Desa Setia total masing -masing 4 jenis tanaman. Jaya Kecamatan Teriak Kabupaten Sedangkan family yang paling sedikit Bengkayang. Family yang paling banyak ditemukan adalah Anonnaceae, 
Auriculariaceae, Blechnaceae, Bombaceae, Bromeliaceae, Caricaceae, Dryopteridaceae, Gnetaceae, Moramataceae, Passifloraceae, Poaceae, Rubiaceae, Schizophyllaceae, Tricholomataceae, Vebenaceae dan Zingiberaceae yang masing-masing memiliki 1 jenis tanaman.

\section{Persentasi bagian yang digunakan}

Berdasarkan hasil wawancara yang telah dilakukan, sebanyak 50 spesies tumbuhan sumber pangan yang telah dimanfaatkan oleh masyarakat sekitar hutan tembawang Desa Setia Jaya kecamatan Teriak Kabupaten Bengkayang sebagai pangan. Jenis-jenis yang dimanfaatkan serta bagian tanaman yang dimanfaatkan oleh masyarakat sebagai sumber pangan secara lengkap dapat dilihat pada Gambar 2.

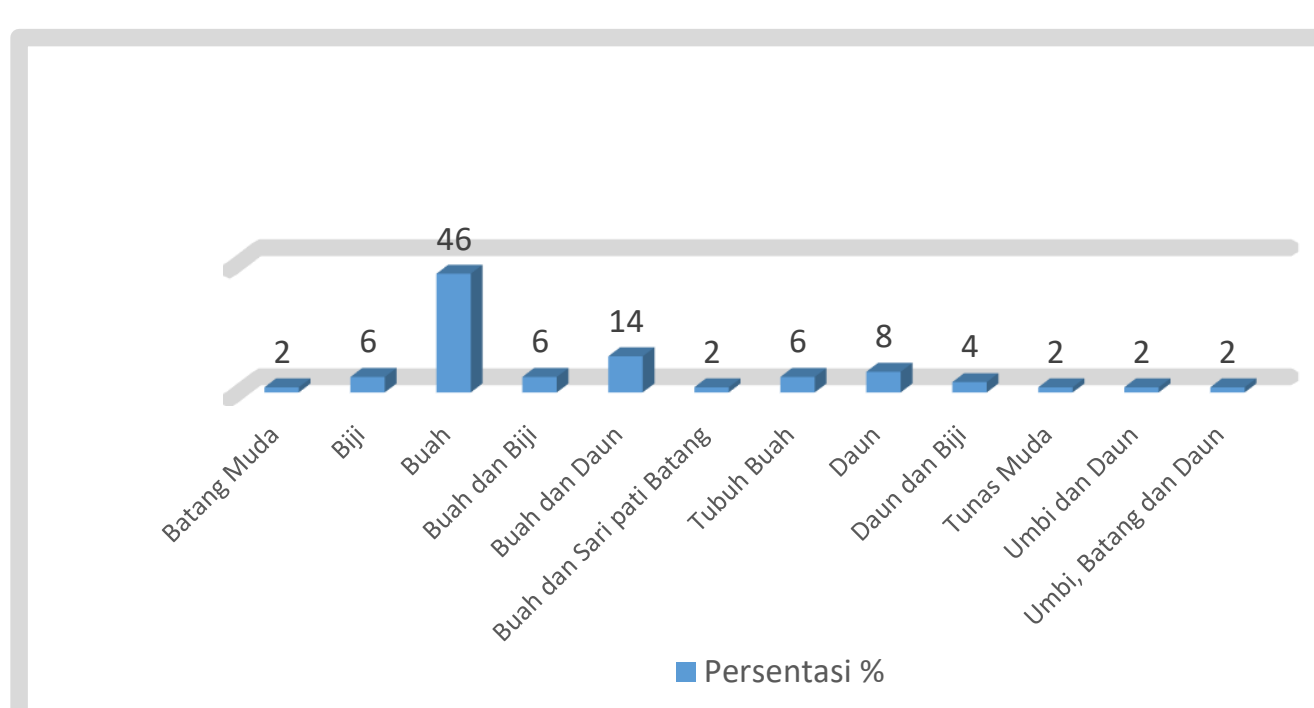

Gambar 2. Bagian Tumbuhan Sumber Pangan Yang Digunakan

Berdasarkan Gambar2. bagian tumbuhan yang digunakan oleh masyarakat sebagi sumber pangan adalah Batang muda dan umbut yaitu 1 spesies, biji yaitu 3 spesies, buah yaitu 23 spesies, Buah dan biji yaitu 3 spesies, buah dan daun 7 spesies, buah dan sari pati batang yaitu 1 spesies, jamur yaitu 3 spesies daun yaitu 4 spesies, daun dan biji yaitu 2 spesies, tunas muda yaitu 1 spesies, umbi dan daun yaitu 1 spesies, batang, umbi dan daun yaitu 1 spesies.

\section{Cara penggunaannya}

Berdasarkan hasil wawancara yang telah dilakukan, sebanyak 50 spesies tumbuhan sumber pangan yang telah dimanfaatkan oleh masyarakat sekitar hutan tembawang Desa Setia Jaya kecamatan Teriak Kabupaten Bengkayang sebagai pangan.terdapat beberapa cara pengolahan yang dilakukan oleh masyarakat. dapat dilihat pada Gambar 3 


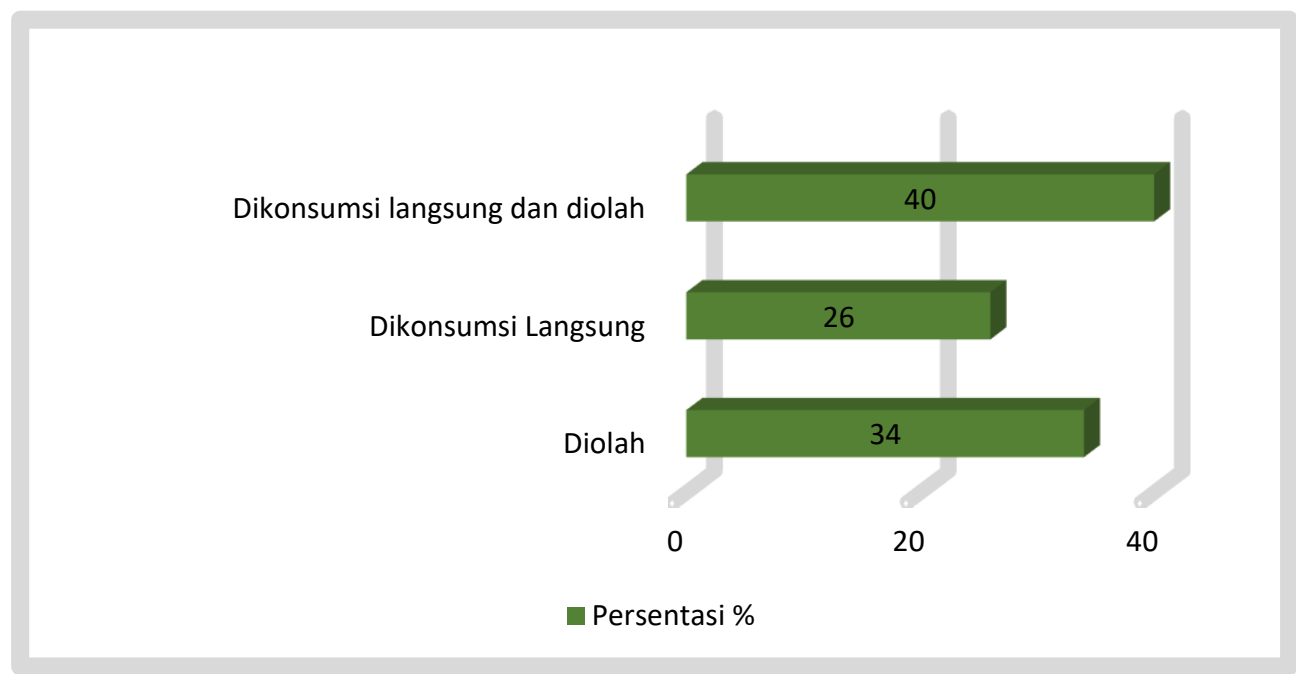

Berdasarkan hasil grafik tumbuhan sumber pangan yang ditemukan pada kawasan Hutan Tembawang Desa setia Jaya Kecamatan Teriak Kabupaten Bengkayang terdapat beberapa cara pengolahan yang dilakukan oleh masyarakat yaitu dikonsumsi langsung dan diolah sebanyai 20 spesies, dikonsumsi langsung sebanyak 13 spesies dan yang diolah sebanyak 17 spesies.
Berdasarkan hasil penelitian yang telah dilakukan, sebanyak 50 spesies tumbuhan sumber pangan yang telah dimanfaatkan oleh masyarakat sekitar hutan tembawang Desa Setia Jaya kecamatan Teriak Kabupaten Bengkayang sebagai pangan. Jenis-jenis tumbuhan sumber pangan berdasarkan kelompok pangan. Dapat dilihat pada Gambar 4.

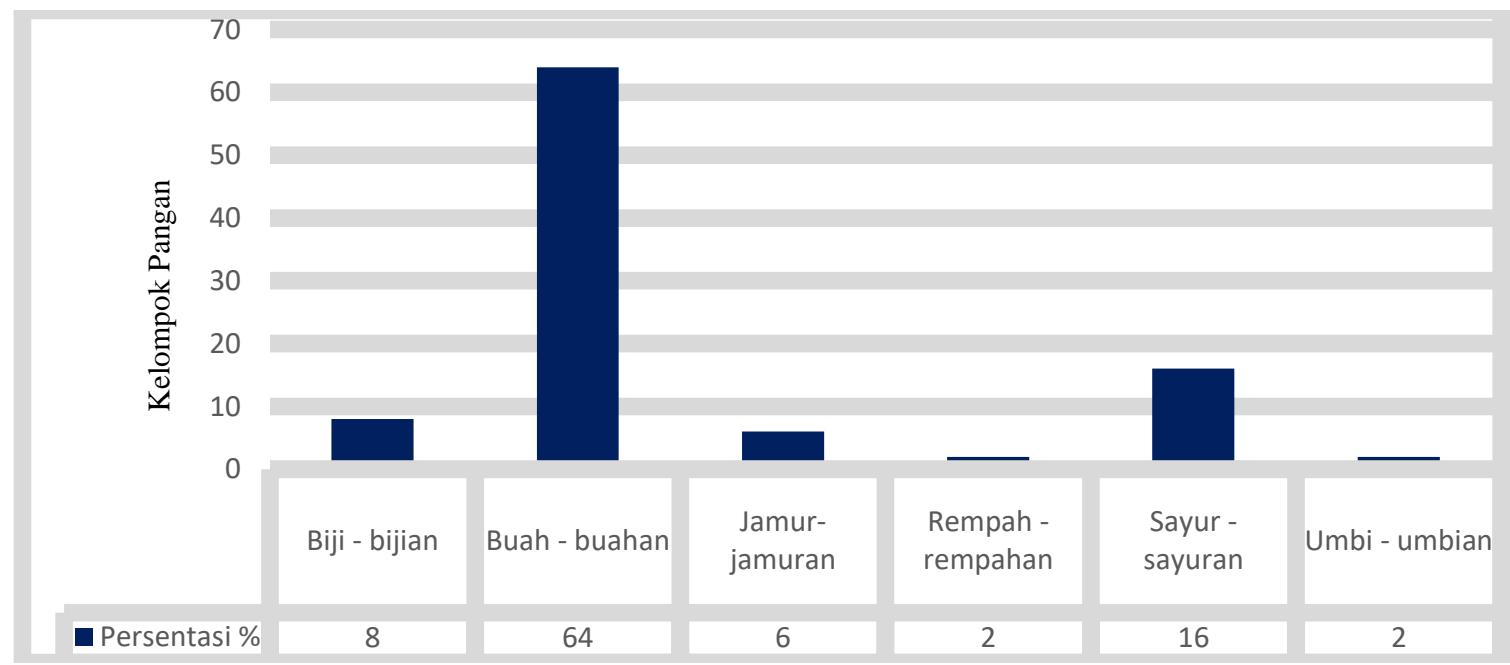

Gambar 4. Kelompok Pangan Tumbuhan Sumber Pangan

Berdasarkan Gambar 4. tumbuhan yang ditemukan pada kawasan hutan tembawang Desa Setia Jaya Kecamatan
Teriak Kabupaten Bengkayang sebagai pangan terdiri dari kelompok Biji-bijian sebanyak 4, buah-buahan sebanyak 32 
spesies, jamur-jamuran sebanyak 3 spesies, rempah-rempah sebanyak 1 spesies, sayur-sayuran sebanyak 8 spesies dan umbi-umbian sebanyak 2 spesies.

Berdasarkan hasil penelitian Firdaus (2011), di Desa Merangun pada Kawasan Hutan Lindung Gunung Naning Kabupaten Sekadau, ditemukan sebanyak 56 jenis tumbuhan pangan, bila dibandingkan dengan hasil penelitian di Desa Setia Jaya, hal yang berbeda yaitu tentang penanaman Bahasa lokal atas jenis tumbuhan pangan tersebut, dikarenakan letak antar kabupaten yang jauh dan berbeda.

Berdasarkan hasil penelitian (kajian literatur) sebelumnya tentang tumbuhan sumber pangan, menurut Tatang et al (2000), penelitian selama bulan September 1996 sampai bulan Agustus 1999 di Desa Tanggerang Kecamatan Jelai Hulu Kabupaten Ketapang ditemukan sebanyak 230 jenis tumbuhan yang dapat dikonsumsi, masing-masing 118 jenis buah-buahan, 70 jenis sayur-sayuran, 17 jenis umbi-umbian, 15 jenis jamur, dan 10 jenis tebu-tebuan. Kemudian penelitian pada bulan September 1996 sampai bulan juli 1997 di Desa Raba dan Desa Nangka Kecamatan Menjalin Kabupaten Landak ditemukan 168 jenis tumbuhan yang dapat dikonsumsi, masing-masing 83 jenis buahbuahan, 62 jenis sayur-sayuran, 7 jenis umbi-umbian, 12 jenis jamur dan 2 jenis tebu-tebuan.

Sedangkan berdasarkan hasil penelitian Nurhaidah (2015), di Desa Sebangun Kecamatan Sebawi Kabupaten Sambas tercatat sebanyak 33 jenis tumbuhan sumber pangan dan yang banyak dimanfaatkan ada 15 jenis tumbuhan sumber pangan dan yang paling sedikit dimanfaatkan sebagai pewarna makanan yaitu 2 jenis tumbuhan. Kemudian menurut hasil penelitian Romana (2015)pada kawasan hutan tembawang Pak Kuning Dusun Petai Bejambu Desa Senakin Kecamatan Sengah Temila tumbuhan sumber pangan yang dimanfaatkan tercatat sebanyak 36 jenis tumbuhan sumber pangan yang dimanfaatkan diantaranya 9 jenis kelompok sayur-sayuran, 25 jenis kelompok buah-buahan dan 2 jenis kelompok umbi-umbian.namun berdasarkan dari kedua penelitian ini perbedaan jumlah tumbuhan pangan yang diperoleh dipengaruhi oleh daerah tempat tinggal dan tempat tumbuh. Oleh karena itu perlu dilakukan pendataan terhadap tumbuhan sumber pangan secara berkala di Desa Setia Jaya Kecamatan Teriak Kabupaten Bengkayang. Tujuannya adalah untuk mengetahui jenis tumbuhan pangan yang ada dan dimanfaatkan oleh masyarakat dalam kawasan Hutan Tembawang Desa Setia Jaya Kecamatan Teriak Kabupaten Bengkayang.

Budaya lokal dalam berladang mengajarkan mereka untuk tidak menebang jenis-jenis tumbuhan sumber pangan tersebut kurang memiliki nilai ekonomis. Bertambahnya penduduk dan semakin sempitnya lahan yang digarap dan adanya pilihan komoditas yang lebih baik melalui konduksi tanaman buahbuahan ungul dan tanaman perdagangan, maka jenis-jenis lokal akan cenderung dikorbankan dan dilupakan (Siregar et al 2000). 
Total jenis tumbuhan yang ditemukan yaitu sebanyak 50 jenis yang terdiri dari 31 jenis kelompok buah-buahan, 3 jenis kelompok umbi-umbian, 9 jenis kelompok sayur-sayuran, 4 jenis biji-bijian, 3 jenis kelompok jamur-jamuran dan1 jenis kelompok rempah-rempah. Adapun famili yang ditemukan yaitu famili Anacarceae, Verberanaceae, Oxalidaceae, Moraceae, Malvaceae, Euphorbiaceae, Myrtaceae, Fabaceae, Auriculariaceae, Sapindaceae, Melastomataceae,

Bromeliaceae, Annonaceae, Poaceae, Arecaceae, Piperceae, Meliaceae, Passifloraceae, Zigiberaceae, Solanaceae, Robiaceae, Dryopteriaceae, Gnetaceae, Blechnaceae, Schizophyllaceae, Caricaceae dan Bombaceae. Famili yang paling banyak ditemukan jenisnya pada lokasin penelitian merupakan jenis umum yang dijumpai pada lokasin penelitian, dan menjadi umum dikonsumsi oleh masyarakat setempat, sehingga merupakan peluang bagi pengembangan tumbuhan lokal yang berpotensi sebagai sumber pangan lainnya yang dapat dibudidayakan oleh masyarakat.

\section{Kesimpulan}

Berdasarkan hasil penelitian dan pembahasan dapat disimpulkan sebagai berikut :

1. Jenis tumbuhan sumber pangan yang dimanfaatkan oleh masyarakat sekitar hutan tembawang Desa Setia Jaya Kecamatan Teriak Kabupaten Bengkayang yaitu sebanyak 50 jenis dan 27 famili.

2. Famili terbanyak adalah dari famili Myrtaceae, Arecaceae, dan Solanaceae masing-masing sebanyak 4 jenis, sedangkan Moraceae dan
Euphorbiaceae masing-masing sebanyak 3 jenis.

3. Bagian yang digunakan sebagai sebagai sumber pangan didominasi oleh bagian buah yaitu sebanyak 28 jenis, dan yamh terendah adalah jenis rempah-rempah dan serealia yaitu sebanyak 1 jenis.

4. Cara penggunaan tumbuhan sumber pangan yaitu dengan cara dimasak atau diolah (23 jenis), dikonsumsi langsung (11 jenis) serta dimasak dan dikonsumsi lansung ( 16 Jenis).

5. Tumbuhan pangan yang memiliki habitus tertinggi adalah habitus pohon yaitu 26 jenis, sedangkan habitus jamur-jamuran dan liana terendah yaitu masing-masing 3 jenis. 6 . Status tumbuhan sumber pangan sebanyak 36 jenis merupakan tumbuhan yang dibudidayakan, sedangkan 14 jenis tanaman nyang tidak dibudidayakan/liar.

\section{Saran}

1. Perlu adanya penelitian lebih lanjut serta kerjasama antara pemerintah dan masyarakat setempat untuk bersamasama menjaga kelestarian hutan tembawang, sehingga tumbuhan pangan yang berada di hutan tembawang Desa Setia jaya tetap lestari agar generasi selanjutnya dapat menikmati tumbuhan sumber pangan hasil hutan tembawang tersebut.

2. Perlu dilakukan kegiatan pembudidayaan terhadap tumbuhan sumber pangan yang terdapat di kawasan hutan tembawang agar tidak punah, mengingat ada beberapa tumbuhan sumber pangan di hutan tembawang Desa Setia jaya yang sudah mulai langka dan susah untuk ditemui.

\section{DAFTAR PUSTAKA}

Ambriansyah. 2010. Teknik Pengenalan jenis dan Pembuatan Herbarium. Damboja Kalimantan Timur. 
$\mathrm{Ba}$ dan Pusat Statistik Kabupaten Sambas. 2012. Kecamatan Sebawi dalam Angka 2011.Katalog Badan Pusat Statistik Sambas.

Firdaus M. 2011. Kajian Etnobotani Tumbuhan Yang Berpotensi Sebagai Sumber Pangan Di Desa Maragun Pada Kawasan Hutan Lindung Gunung Naning Kabupaten Sekadau [Skripsi]. Pontianak : Fakultas Kehutanan, Universitas Tanjungpura.

Gammaruddin, Handayani R, Sukmawati ST. 2004. Etnobotani Komunitas Tau taa Wana Bulang. Palu:Yayasan Merah Putih.

Kementrian Kehutanan. 2010. Penggelolaan dan Pemanfaatan Sumberdaya Hutan Untuk Mendukung Peningkatan Produksi Pangan. Disampaikan pada Seminar Nasional Ketahanan Pangan Menuju "Feed The World". Jakarta.

Napagoda M. T, Thamudi S, dan Diroshi F. 2018, An Ethnobotanical Study of the medical Plants Used as AntiInflammatory Remedies in Gampaha District, Western Proviebce, Sri Langka. Jurnal Scientifica. Vol 2018, Article ID 9395052: 1-8

Nurhidayah Y. Lovadi I. Linda R. 2015. Tumbuhan Berpotensi Bahan Pangan Di Desa Sebangun Kecamatan Sebawi Kabupaten Sambas. Jurnal Protobiont 4(1).

Romana. Burhanuddin. Thamrin E. 2018. Tumbuhan Sumber Pangan Yang Dikonsumsi Oleh Masyarakat Pada Tembawang Pak Kuning Di Sengah Temila. Jurnal Lestari 6(4).
Rugayah, Retnowati A, Windadari F. I \& Hidayat. 2004. Pengumpulan Data Taksonomi. Dalam Rugayah, Elisabeth A, Widjaja. Prapatiwi. Pedoman Pengumpulan Data Keanekaragaman Flora. Pusat Penelitian Biologi. LIPI. Bogor

Saragih B. 2011. Agribisnis paradigma Baru Pembangunan Ekomomi Berbasis Pertanian. Bogor. Yayasan Mulia Pesada.

Setiyawan, A. D, Indrowuryanto, winanmo, $\mathrm{K}$ dan Susilowati, A. 2005. Tumbyhan Mangrove di Pesisir Jawa Tengah. Jurusan Biologi FMIPA Universitas Sebelas Maret. Surakarta.

Siregar M. Sambas EN. Ismail. 2000. Peranan Masyarakat Adat Dalam Melestarikan Plasma Nutfah Buahbuahan. Prosiding Seminar Hari Cinta Puspa dan Satwa Nasional. Pulitbang Biologi-LIPI. Bogor.

Suhardi SA, Sudjoko, Minamingsih. 2002. Hutan dan Kebun Sebagai Sumber Pangan Nasional. Jakarta.Kanisius.

Sumarlin D, Dirhamsyah M, Adrian H. 2015. Identifikasi Tumbuhan sumber Pangan di Hutan Tembawang Desa Aur Sepauk Kecamatan Sengah Temila kabupatenLandak.Jurnal Hutan Lestari 4(1).

Tatang L. Victor F. Uwan S. Sood MM. Bayer A. Hasiwan D. Silun. 2000. Kalimantan : Bumi Yang Kaya Makanan. Pontianak : Masyarakat Adat Dayak Mempawah dan Dayak Jalai Bekerjasama denga Institut Dayakologi. 


\section{Lampiran 1}

Tabel 1. Tumbuhan Sumber Pangan Yang Ditemukan Pada Kawasan Hutan Tembawang Desa Setia Jaya Kecamatan Teriak Kabupaten bengkayang.

\begin{tabular}{|c|c|c|c|c|c|c|c|}
\hline No & $\begin{array}{l}\text { Nama } \\
\text { Lokal }\end{array}$ & $\begin{array}{c}\text { Nama } \\
\text { Indonesia }\end{array}$ & Nama Ilmiah & Famili & Habitus & Habitat & $\begin{array}{c}\text { Status di } \\
\text { Alam (L/D) }\end{array}$ \\
\hline (1) & (2) & (3) & (4) & (5) & (6) & (7) & (8) \\
\hline 1 & $\begin{array}{l}\text { Asam } \\
\text { Mangga }\end{array}$ & Mangga & Mangifera indica $\mathrm{L}$ & Anarcardiaceae & Pohon & $\begin{array}{l}\text { Dataran } \\
\text { rendah } \\
\text { dengan } \\
\text { tanah PMK }\end{array}$ & Dibudidayakan \\
\hline 2 & Balimbing & Belimbing & $\begin{array}{l}\text { Averrhoa } \\
\text { carambola } \mathrm{L}\end{array}$ & Oxalidaceae & Pohon & $\begin{array}{l}\text { Dataran } \\
\text { rendah } \\
\text { dengan } \\
\text { tanah PMK }\end{array}$ & Dibudidayakan \\
\hline 3 & $\begin{array}{l}\text { Barinang } \\
\text { Wuluh }\end{array}$ & $\begin{array}{l}\text { Belimbing } \\
\text { wuluh }\end{array}$ & Averrhoa bilimbiL & Oxalidaceae & Pohon & $\begin{array}{l}\text { Dataran } \\
\text { rendah } \\
\text { dengan } \\
\text { tanah PMK }\end{array}$ & Dibudidayakan \\
\hline 4 & Bebuas & Bebuas & $\begin{array}{l}\text { Premna foetida } \\
\text { Reiwn }\end{array}$ & Verbenaceae & Pohon & $\begin{array}{l}\text { Semak } \\
\text { belukar }\end{array}$ & Liar \\
\hline 5 & Cempedak & Cempedak & $\begin{array}{l}\text { Artocarpus } \\
\text { integar(Thunb.) } \\
\text { Merr }\end{array}$ & Moraceae & Pohon & $\begin{array}{l}\text { Dataran } \\
\text { rendah } \\
\text { dengan } \\
\text { tanah PMK }\end{array}$ & Dibudidayakan \\
\hline 6 & Cengkodok & Lingkodok & $\begin{array}{l}\text { Melastoma } \\
\text { septemnervium } \\
\text { Lour }\end{array}$ & Melastomataceae & Perdu & $\begin{array}{l}\text { Semak } \\
\text { Belukar }\end{array}$ & Liar \\
\hline 7 & Durian & Durian & $\begin{array}{l}\text { Durio zibethinus } \\
\text { Murr }\end{array}$ & Bombaceae & Pohon & $\begin{array}{l}\text { Dataran } \\
\text { rendah } \\
\text { dengan } \\
\text { tanah PMK }\end{array}$ & Dibudidayakan \\
\hline 8 & $\begin{array}{l}\text { Durian } \\
\text { Kawai }\end{array}$ & $\begin{array}{l}\text { Durian } \\
\text { Kawai }\end{array}$ & $\begin{array}{l}\text { Durio kutejensis } \\
\text { Hassk. \& Becc. }\end{array}$ & Malvaceae & Pohon & $\begin{array}{l}\text { Dataran } \\
\text { rendah } \\
\text { dengan } \\
\text { tanah PMK }\end{array}$ & Dibudidayakan \\
\hline 9 & Gatah & Karet & $\begin{array}{l}\text { Hevea } \\
\text { brasiliensisMuell. } \\
\text { Arg. }\end{array}$ & Euphorbiaceae & Pohon & $\begin{array}{l}\text { Dataran } \\
\text { rendah } \\
\text { dengan } \\
\text { tanah PMK }\end{array}$ & Dibudidayakan \\
\hline 10 & Jamu Ai' & Jambu air & $\begin{array}{l}\text { Syzygium aqueum } \\
\text { (Burm.f.) Alston, } \\
1929\end{array}$ & Myrtaceae & Pohon & $\begin{array}{l}\text { Dataran } \\
\text { rendah } \\
\text { dengan } \\
\text { tanah PMK }\end{array}$ & Dibudidayakan \\
\hline 11 & Jamu Bege' & Jambu Batu & Psidium guajava $\mathrm{L}$ & Myrtaceae & Pohon & $\begin{array}{l}\text { Dataran } \\
\text { rendah } \\
\text { dengan } \\
\text { tanah PMK }\end{array}$ & Dibudidayakan \\
\hline 12 & Jamu bol & Jambu Bol & $\begin{array}{l}\text { Syzygium } \\
\text { malaccense }(\mathrm{L} .) \\
\text { Merr. \& Perry, } \\
1938\end{array}$ & Myrtaceae & Pohon & $\begin{array}{l}\text { Dataran } \\
\text { rendah } \\
\text { dengan } \\
\text { tanah PMK }\end{array}$ & Dibudidayakan \\
\hline 13 & Jaring & Jengkol & $\begin{array}{l}\text { Archidendron } \\
\text { pauciflorum } \\
\text { (Benth.) } \\
\text { 1.C.Nielsen }\end{array}$ & Fabaceae & Pohon & $\begin{array}{l}\text { Dataran } \\
\text { rendah } \\
\text { dengan } \\
\text { tanah PMK }\end{array}$ & Dibudidayakan \\
\hline 14 & Kadondong & Kedondong & Spondias dulcisL. & Anarcardiaceae & Pohon & $\begin{array}{l}\text { Dataran } \\
\text { rendah } \\
\text { dengan } \\
\text { tanah PMK }\end{array}$ & Dibudidayakan \\
\hline 15 & Kalengkeng & Lengkeng & $\begin{array}{l}\text { Dimocarpus logan } \\
\text { Lour }\end{array}$ & Sapindaceae & Pohon & $\begin{array}{l}\text { Dataran } \\
\text { rendah }\end{array}$ & Dibudidayakan \\
\hline
\end{tabular}


JURNAL HUTAN LESTARI (2020)

Vol. 8 (4): 759 - 764

\begin{tabular}{|c|c|c|c|c|c|c|c|}
\hline No & $\begin{array}{l}\text { Nama } \\
\text { Lokal }\end{array}$ & $\begin{array}{c}\text { Nama } \\
\text { Indonesia }\end{array}$ & Nama Ilmiah & Famili & Habitus & Habitat & $\begin{array}{c}\text { Status di } \\
\text { Alam (L/D) }\end{array}$ \\
\hline (1) & (2) & (3) & (4) & (5) & (6) & (7) & (8) \\
\hline 16 & Kaminting & Kemiri & $\begin{array}{l}\text { Aleurites } \\
\text { moluccana }(\mathrm{L}) \\
\text { Willd., } 1805\end{array}$ & Euphorbiaceae & Pohon & $\begin{array}{l}\text { dengan } \\
\text { tanah PMK } \\
\text { Dataran } \\
\text { rendah } \\
\text { dengan } \\
\text { tanah PMK }\end{array}$ & Dibudidayakan \\
\hline 17 & Kates & Pepaya & Carica papaya L. & Caricaceae & Perdu & $\begin{array}{l}\text { Semak } \\
\text { belukar }\end{array}$ & Dibudidayakan \\
\hline 18 & Keladi & Talas & $\begin{array}{l}\text { Colocasia } \\
\text { esculenta }(L) \\
\text { Schoot }\end{array}$ & Arecaceae & Terna & $\begin{array}{l}\text { Tepian } \\
\text { Rawa }\end{array}$ & Liar \\
\hline 19 & Kelampai & Kelampai & $\begin{array}{l}\text { Elateriospermum } \\
\text { tapos Blume }\end{array}$ & Euphorbiaceae & Pohon & $\begin{array}{l}\text { Dataran } \\
\text { rendah } \\
\text { dengan } \\
\text { tanah PMK }\end{array}$ & Dibudidayakan \\
\hline 20 & Klaweh & Klaweh & $\begin{array}{l}\text { Artocarpus } \\
\text { camansi(Parkinson) } \\
\text { Fosberg }\end{array}$ & Moraceae & Pohon & $\begin{array}{l}\text { Dataran } \\
\text { rendah } \\
\text { dengan } \\
\text { tanah PMK }\end{array}$ & Dibudidayakan \\
\hline 21 & Koko & $\begin{array}{l}\text { Kokoa / } \\
\text { Coklat }\end{array}$ & $\begin{array}{l}\text { Theobroma cacao } \\
\mathrm{L}\end{array}$ & Malvaceae & Pohon & $\begin{array}{l}\text { Dataran } \\
\text { rendah } \\
\text { dengan } \\
\text { tanah PMK }\end{array}$ & Dibudidayakan \\
\hline 22 & Kulat Putih & $\begin{array}{l}\text { Jamur } \\
\text { Tiram }\end{array}$ & $\begin{array}{l}\text { Pleurotus ostreatus } \\
\text { Champ. Jura. Vosg }\end{array}$ & Tricholomataceae & $\begin{array}{l}\text { Jamur- } \\
\text { jamuran }\end{array}$ & $\begin{array}{l}\text { Batang } \\
\text { pohon/kayu } \\
\text { yang mati }\end{array}$ & Liar \\
\hline 24 & $\begin{array}{l}\text { Kulat } \\
\text { Kuping }\end{array}$ & $\begin{array}{l}\text { Jamur } \\
\text { Kuping }\end{array}$ & $\begin{array}{l}\text { Auricularia } \\
\text { polytricha(Mont.) } \\
\text { Sacc. }\end{array}$ & Auriculariaceae & $\begin{array}{l}\text { Jamur- } \\
\text { jamuran }\end{array}$ & $\begin{array}{l}\text { Batang } \\
\text { pohon/kayu } \\
\text { yang mati }\end{array}$ & Liar \\
\hline 25 & Lamiding & $\begin{array}{l}\text { Pakis } \\
\text { Merah }\end{array}$ & $\begin{array}{l}\text { Stenochalaena } \\
\text { palustris(Burm.F.) } \\
\text { Bedd, } 1876\end{array}$ & Blechnaceae & Herba & $\begin{array}{l}\text { Semak } \\
\text { belukar }\end{array}$ & Liar \\
\hline 26 & Matoa & Matoa & $\begin{array}{l}\text { Pometia } \\
\text { pinnataForst \& } \\
\text { Forst }\end{array}$ & Sapindaceae & Pohon & $\begin{array}{l}\text { Dataran } \\
\text { rendah } \\
\text { dengan } \\
\text { tanah PMK }\end{array}$ & Dibudidayakan \\
\hline 27 & Melinjo & Melinjo & Gnetum gnemonL & Gnetaceae & Pohon & $\begin{array}{l}\text { Dataran } \\
\text { rendah } \\
\text { dengan } \\
\text { tanah PMK }\end{array}$ & Dibudidayakan \\
\hline 28 & Mengkudu & Mengkudu & $\begin{array}{l}\text { Morinda citrifolia } \\
\mathrm{L}\end{array}$ & Robiaceae & Pohon & $\begin{array}{l}\text { Dataran } \\
\text { rendah } \\
\text { dengan } \\
\text { tanah PMK }\end{array}$ & Dibudidayakan \\
\hline 29 & Mentawak & Mentawa & $\begin{array}{l}\text { Artocarpus } \\
\text { anisophyllus Miq }\end{array}$ & Moraceae & Pohon & $\begin{array}{l}\text { Dataran } \\
\text { rendah } \\
\text { dengan } \\
\text { tanah PMK }\end{array}$ & Dibudidayakan \\
\hline 30 & Nanas & Nanas & $\begin{array}{l}\text { Ananas } \\
\operatorname{comosus}(\mathrm{L} .) \text { Merr. }\end{array}$ & Bromeliaceae & Herba & $\begin{array}{l}\text { Semak } \\
\text { belukar }\end{array}$ & Dibudidayakan \\
\hline 31 & Nangka & Nangka & $\begin{array}{l}\text { Artocarpus } \\
\text { heterophyllusLamk }\end{array}$ & Moraceae & Pohon & $\begin{array}{l}\text { Dataran } \\
\text { rendah } \\
\text { dengan } \\
\text { tanah PMK }\end{array}$ & Dibudidayakan \\
\hline 32 & $\begin{array}{l}\text { Nangka } \\
\text { Belanda }\end{array}$ & Sirsak & Annona muricata $\mathrm{L}$ & Annonaceae & Pohon & $\begin{array}{l}\text { Dataran } \\
\text { rendah } \\
\text { dengan } \\
\text { tanah PMK }\end{array}$ & Dibudidayakan \\
\hline 33 & Paku ubant & Pakis Hijau & Nephrolepis & Dryopteridaceae & Herba & Semak & Liar \\
\hline
\end{tabular}


JURNAL HUTAN LESTARI (2020)

Vol. 8 (4): 759 - 764

\begin{tabular}{|c|c|c|c|c|c|c|c|}
\hline No & $\begin{array}{l}\text { Nama } \\
\text { Lokal }\end{array}$ & $\begin{array}{c}\text { Nama } \\
\text { Indonesia }\end{array}$ & Nama Ilmiah & Famili & Habitus & Habitat & $\begin{array}{c}\text { Status di } \\
\text { Alam (L/D) }\end{array}$ \\
\hline (1) & (2) & (3) & (4) & (5) & (6) & (7) & (8) \\
\hline & & & $\begin{array}{l}\text { cordifolia }(\mathrm{L}) \mathrm{k} . \\
\text { Presl }\end{array}$ & & & belukar & \\
\hline 34 & Petai & Petai & $\begin{array}{l}\text { Parkia speciosa } \\
\text { hassk }\end{array}$ & Fabaceae & Pohon & $\begin{array}{l}\text { Dataran } \\
\text { rendah } \\
\text { dengan } \\
\text { tanah PMK }\end{array}$ & Dibudidayakan \\
\hline 35 & Pinang & Pinang & Areca catechu $\mathrm{L}$ & Arecaceae & Pohon & $\begin{array}{l}\text { Dataran } \\
\text { rendah } \\
\text { dengan } \\
\text { tanah PMK }\end{array}$ & Liar \\
\hline 36 & Rabungk & Bambu & $\begin{array}{l}\text { Bambusa vulgaris } \\
\text { Schard }\end{array}$ & Poaceae & Pohon & $\begin{array}{l}\text { Semak } \\
\text { belukar }\end{array}$ & Liar \\
\hline 37 & Sagu & Sagu & $\begin{array}{l}\text { Metroxylon sagu } \\
\text { Rottb }\end{array}$ & Arecaceae & Pohon & $\begin{array}{l}\text { Dataran } \\
\text { rendah } \\
\text { dengan } \\
\text { tanah PMK }\end{array}$ & Dibudidayakan \\
\hline 38 & Sahang & Lada & Piper nigrum $\mathrm{L}$ & Pipercaceae & Liana & $\begin{array}{l}\text { Semak } \\
\text { belukar }\end{array}$ & Dibudidayakan \\
\hline 39 & Salak & Salak & $\begin{array}{l}\text { Salacca } \\
\text { zalacca(Gaertn.) } \\
\text { Voss }\end{array}$ & Arecaceae & Perdu & $\begin{array}{l}\text { Semak } \\
\text { belukar }\end{array}$ & Dibudidayakan \\
\hline 40 & Sarikant & Langsat & $\begin{array}{l}\text { Lansium } \\
\text { dosmeticumCorr }\end{array}$ & Meliaceae & Pohon & $\begin{array}{l}\text { Dataran } \\
\text { rendah } \\
\text { dengan } \\
\text { tanah PMK }\end{array}$ & Dibudidayakan \\
\hline 41 & Satol & Kecapi & $\begin{array}{l}\text { sandoricum } \\
\text { koetjapeMerr. }\end{array}$ & Meliaceae & Pohon & $\begin{array}{l}\text { Dataran } \\
\text { rendah } \\
\text { dengan } \\
\text { tanah PMK }\end{array}$ & Dibudidayakan \\
\hline 42 & Sebura & Lelatup & $\begin{array}{l}\text { Passtiflora foetida } \\
\mathrm{L}\end{array}$ & Passifloraceae & Liana & $\begin{array}{l}\text { Semak } \\
\text { belukar }\end{array}$ & Liar \\
\hline 43 & Sirih & Sirih & Piper betle L & Pipercaceae & Herba & $\begin{array}{l}\text { Semak } \\
\text { belukar }\end{array}$ & Liar \\
\hline 44 & Sukun & Sukun & $\begin{array}{l}\text { Artocarpus altilis } \\
\text { (Parkinson) } \\
\text { Fosberg }\end{array}$ & Moraceae & Pohon & $\begin{array}{l}\text { Dataran } \\
\text { rendah } \\
\text { dengan } \\
\text { tanah PMK }\end{array}$ & Dibudidayakan \\
\hline 45 & $\begin{array}{l}\text { Tarung } \\
\text { Asam }\end{array}$ & $\begin{array}{l}\text { Terung } \\
\text { Asam }\end{array}$ & Solamun ferox $\mathrm{L}$ & Solanaceae & Terna & $\begin{array}{l}\text { Semak } \\
\text { belukar }\end{array}$ & Dibudidayakan \\
\hline 46 & $\begin{array}{l}\text { Tarung } \\
\text { Ungu }\end{array}$ & $\begin{array}{l}\text { Terung } \\
\text { Ungu }\end{array}$ & $\begin{array}{l}\text { Solanum } \\
\text { melongena } \mathrm{L}\end{array}$ & Solanaceae & Perdu & $\begin{array}{l}\text { Semak } \\
\text { belukar }\end{array}$ & Dibudidayakan \\
\hline 47 & $\begin{array}{l}\text { Tepo } \\
\text { Rungkang }\end{array}$ & $\begin{array}{l}\text { Lempuyang } \\
\text { Wangi }\end{array}$ & $\begin{array}{l}\text { Zigiber } \\
\text { aromaticum } \mathrm{Val}\end{array}$ & Zigiberaceae & Terna & $\begin{array}{l}\text { Semak } \\
\text { belukar }\end{array}$ & Dibudidayakan \\
\hline 48 & $\begin{array}{l}\text { Tomat } \\
\text { hutan }\end{array}$ & Ciplukan & $\begin{array}{l}\text { Physalis angulata } \\
\mathrm{L}\end{array}$ & Solanaceae & Herba & $\begin{array}{l}\text { Semak } \\
\text { belukar }\end{array}$ & Liar \\
\hline 49 & Ubah Ube & $\begin{array}{l}\text { Daun } \\
\text { Salam }\end{array}$ & $\begin{array}{l}\text { Syzygium } \\
\text { polyanthum(Wight) } \\
\text { Walpers }\end{array}$ & Myrataceae & Pohon & $\begin{array}{l}\text { Dataran } \\
\text { rendah } \\
\text { dengan } \\
\text { tanah PMK }\end{array}$ & Dibudidayakan \\
\hline 50 & Ubi kayu & Ubi Kayu & $\begin{array}{l}\text { Manihot } \\
\text { utilissimaPohl }\end{array}$ & Euphorbiaceae & Herba & $\begin{array}{l}\text { Semak } \\
\text { belukar }\end{array}$ & Dibudidayakan \\
\hline
\end{tabular}

Sumber Data : Analisis Data 2019 


\section{Lampiran 2}

Tabel 2. Analisis Use Value (UV)

\begin{tabular}{|c|c|c|c|c|c|}
\hline No & Nama Tumbuhan & Nama Latin & $\begin{array}{c}\text { Total } \\
\text { responden } \\
\text { yang } \\
\text { mengetahui } \\
\end{array}$ & $\begin{array}{c}\text { Total } \\
\text { Keseluruhan } \\
\text { Responden }\end{array}$ & $\begin{array}{c}\text { Total } \\
\text { Use } \\
\text { Value }\end{array}$ \\
\hline (1) & $(2)$ & (3) & (4) & (5) & (6) \\
\hline 1 & Mangga & Mangifera indica $\mathrm{sp}$ & 30 & 30 & 1 \\
\hline 2 & Belimbing & Averrhoa carambola $\mathrm{L}$ & 30 & 30 & 1 \\
\hline 3 & Belimbing Wuluh & Averrhoa bilimbi $L$ & 29 & 30 & 0.966667 \\
\hline 4 & Bebuas & Premmafoetida Reinw & 29 & 30 & 0.966667 \\
\hline 5 & Cempedak & Atorcarpus integar (Thumb.) Merr & 29 & 30 & 0.966667 \\
\hline 6 & Lingkodok & Melastoma septemnervium Lour & 23 & 30 & 0.766667 \\
\hline 7 & Durian & Durio zibethinus Murr & 30 & 30 & 1 \\
\hline 8 & Durian Kawai & Durio kutejensis Hassk. \& Becc. & 29 & 30 & 0.966667 \\
\hline 9 & Karet & Hevea brasilenss Muell. Arg. & 30 & 30 & 1 \\
\hline 10 & Jambu Air & Syzygium aqueum (Burm.f.) Alton, 1929 & 18 & 30 & 0.6 \\
\hline 11 & Jambu Batu & Psidium guajava $\mathrm{L}$ & 21 & 30 & 0.7 \\
\hline 12 & Jambu Bol & Syzygium malaccence(L.) Merr. \& Perry, 1938 & 16 & 30 & 0.533333 \\
\hline 13 & Jengkol & Archidendron pauciflorum (Benth.) I.C.Nielsen & 21 & 30 & 0.7 \\
\hline 14 & Kedondong & Spondias dulcis $\mathrm{L}$ & 20 & 30 & 0.666667 \\
\hline 15 & Lengkeng & Dimocarpus logan Lour & 19 & 30 & 0.633333 \\
\hline 16 & Kemiri & Aleurites moluccana (L) Willd,. 1805 & 7 & 30 & 0.233333 \\
\hline 17 & Pepaya & Carica papaya $\mathrm{L}$ & 30 & 30 & 1 \\
\hline 18 & Keladi & Colocasia esculenta (L) Schoot & 18 & 30 & 0.6 \\
\hline 19 & Kelampai & Elateriospermum tapos Blume & 9 & 30 & 0.3 \\
\hline 20 & Klaweh & Artocarpus camansi & 18 & 30 & 0.6 \\
\hline 21 & Kokoa/coklat & Theobroma cacao $\mathrm{L}$ & 30 & 30 & 1 \\
\hline 22 & Jamur Putih & Pleurotus ostreatusChamp. Jura. Vosg & 8 & 30 & 0.266667 \\
\hline 23 & Cendawan & Schizophyllum commune Fries (1815) & 6 & 30 & 0.2 \\
\hline 24 & Jamur Kuping & Auricularia polytricha (Mont.) Sacc. & 6 & 30 & 0.2 \\
\hline 25 & Pakis Merah & Stenochalaena palustris (Burm.F) Bedd, 1876 & 30 & 30 & 1 \\
\hline 26 & Matoa & Pometia pinnata Forst \& Forst & 18 & 30 & 0.6 \\
\hline 27 & Melinjo & Gnetum gnemo L & 16 & 30 & 0.533333 \\
\hline 28 & Mengkudu & Morinda citrifolia $\mathrm{L}$ & 16 & 30 & 0.533333 \\
\hline 29 & Mentawa & Artocarpus anisophyllus Miq & 18 & 30 & 0.6 \\
\hline 30 & Nanas & Ananas comosus (L) Merr. & 9 & 30 & 0.3 \\
\hline 31 & Nangka & Artocarpus heterophyllus Lamk & 30 & 30 & 1 \\
\hline 32 & Sirsak & Annona murica $\mathrm{L}$ & 30 & 30 & 1 \\
\hline 33 & Pakis Hijau & Nephrolepis cordifolia (L) k. Presl & 30 & 30 & 1 \\
\hline 34 & Petai & Parkia speciosa Hassk. & 30 & 30 & 1 \\
\hline 35 & Pinang & Areca catechu $\mathrm{L}$ & 28 & 30 & 0.933333 \\
\hline 36 & Bambu/Rebung & Bambusa vulgaris Schard & 30 & 30 & 1 \\
\hline 37 & Sagu & Metroxylon sagu Rottb & 11 & 30 & 0.366667 \\
\hline 38 & Lada & Piper nigrum $\mathrm{L}$ & 15 & 30 & 0.5 \\
\hline 39 & Salak & Salacca zalacca (Gaertn.) Voss & 15 & 30 & 0.5 \\
\hline 40 & Langsat & Lansium dosmeticum Corr. & 20 & 30 & 0.666667 \\
\hline 41 & Kecapi & Sndoricumkoetjape Merr. & 15 & 30 & 0.5 \\
\hline 42 & Lelatup & Passiflora foetida $\mathrm{L}$ & 5 & 30 & 0.166667 \\
\hline 43 & Sirih & Piper betle $\mathrm{L}$ & 14 & 30 & 0.466667 \\
\hline 44 & Sukun & Artocarpus altilitis (Parkinson) Fosberg & 14 & 30 & 0.466667 \\
\hline 45 & Terung Asam & Solamun ferox $\mathrm{L}$ & 17 & 30 & 0.566667 \\
\hline 46 & Terung Ungu & Solamum melongena $\mathrm{L}$ & 19 & 30 & 0.633333 \\
\hline 47 & Lempuyang Wangi & Sigiber aromaticum Val & 17 & 30 & 0.566667 \\
\hline 48 & Ciplukan & Physalis angulata $\mathrm{L}$ & 12 & 30 & 0.4 \\
\hline
\end{tabular}


JURNAL HUTAN LESTARI (2020)

Vol. 8 (4): 759 - 764

49 Daun Salam Zygygium polyanthum (Wight) Walpers

Manihot utilissima Pohl

30

30

Ubi Kayu

30

0.5

Sumber Data : Analisis Data 2019 